
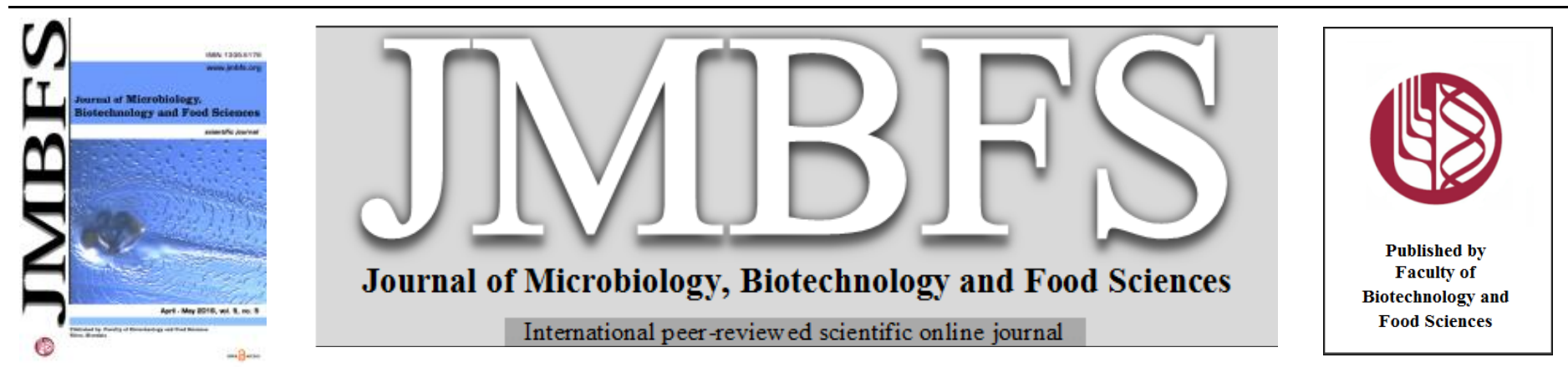

\title{
CHEMICAL PROFILE AND ANTIMICROBIAL ACTIVITIES OF TWO EDIBLE MUSHROOMS (Termitomyces robustus and Lentinus squarrosulus)
}

\section{Funmilayo Borokini ${ }^{1}$, Labunmi Lajide $^{2}$, Tolu Olaleye $^{3}$ Aline Boligon ${ }^{4}$ Margareth Athayde $^{4}$, Isaac Adesina $^{1}$}

\section{Address(es):}

${ }^{1}$ Department of Science Laboratory Technology, Rufus Giwa Polytechnic,P.M.B. 1019, Owo, Ondo State, Nigeria.

${ }^{2}$ Department of Chemistry, Federal University of Technology, Akure, P.M.B 704, Akure, Ondo State, Nigeria.

${ }^{3}$ Department of Biochemistry, Federal University of Technology, Akure, P.M.B 704, Akure, Ondo State, Nigeria.

${ }^{4}$ Departamento de Farmacia Industrial, Universidale de Federal Santa Maria, Campus Universitario - Camobi 97100-900 Santa Maria RS, Brasil.

*Corresponding author: borokinif59@yahoo.com

doi: 10.15414/jmbfs.2016.5.5.416-423

\section{ARTICLE INFO}

Received 22. 5. 2015

Revised 19. 12. 2015

Accepted 4. 1. 2016

Published 1. 4. 2016

Regular article

open $\partial_{\text {Access }}$

\begin{abstract}
The methanol extracts of two edible mushrooms; Termitomyces robustus (ewe) and Lentinus squarrosulus (erirokiro) were screened for phytochemicals of medicinal importance and the chemical profile investigated using standard analytical methods with the aim of assessing their health promoting properties. Both mushrooms tested positive to flavonoids, saponin, tannin and terpenoid but negative to steroid, anthraquinone and phlobatannin. The results of proximate compositions in \% were; moisture contents $(7.22 \pm 0.07 ; 11.03 \pm$ $0.21)$, crude protein $(31.34 \pm 0.01 ; 42.77 \pm 0.57)$, ash $(7.07 \pm 0.04 ; 10.45 \pm 0.43)$, crude fibre $(4.07 \pm 0.18 ; 9.48 \pm 0.04)$, crude fat (3.71 $\pm 0.16 ; 6.76 \pm 0.22)$, carbohydrate by difference $(24.90 \pm 0.11 ; 41.27 \pm 0.19)$, calorific value in kcal $(331.55 \pm 3.41 ; 342.35 \pm 3.09)$, and total dietary fibre $(10.21 \pm 0.00 ; 11.68 \pm 0.00)$. The anti-nutrient factors in $\mathrm{mg} / \mathrm{g}$ were; tannin $(3.25 \pm 0.80 ; 7.40 \pm 0.14)$ oxalate $(1.53 \pm$ $0.00 ; 1.71 \pm 0.07)$, and phytate $(1.48 \pm 0.06 ; 1.94 \pm 0.05)$. Mineral elements, vitamins, essential and non-essential amino acids in substantial quantities were detected in the mushrooms. The phenolic compounds identified and quantified were gallic acid, catechin,chlorogenic acid, caffeic acid, ellagic acid, epicatechin, rutin, isoquercitrin, quercitrin, quercetin and kaempferol.The mushrooms exhibited various antifungi and antimicrobial activities. The two mushrooms possessed good nutritional and chemical qualities and could be sources of many different nutraceuticals.
\end{abstract}

Keywords: Phytochemicals, proximate, flavonoids, Polyphenols, Termitomycesrobustus, Lentinussquarrosulus

\section{INTRODUCTION}

Mushrooms are the higher fungi which have long been used for food and medicinal purposes. Fresh and preserved mushrooms are consumed in many countries as a delicacy, particularly for their specific aroma and texture (Pavel, 2012). They have rich nutritional value with high protein content (up to $44.93 \%$ ), vitamins, minerals, fibers, trace elements and low calories and lack cholesterol (Hrudayanath and Sameer, 2014; Agahar- Murugkar and Subbulakshmi, 2005; Wani et al., 2010). Wild mushrooms are becoming more and more important in our diet due to their value as food as well as their medical and nutraceutical values (Chang and Miles, 2004). Their global economic value is now increasing as a result of their nutritional, organoleptic, and pharmacological characteristics (Diez and Alvarez, 2001; Solak et al., 2006). The leading countries in mushroom production are China, US, Netherlands, India and Vietnam, according to recent FAO report (FAO, 2014; Yaoqi et al., 2014). Mushrooms production can alleviate poverty in rural communities and improve the diversification of agricultural production (Godfrey $\boldsymbol{e t}$ al., 2010) as well as national economy if given its proper place especially now that mushrooms are being considered as an alternative food source to provide adequate nutrition for world's increasing population. Several researches have established some edible mushroom species as sources of physiological agents for medicinal applications, possessing antitumour, cardiovascular, antiviral, antibacterial and other activities (Halpern and Miller, 2002; Wasser, 2002; Chang, 1996). Each mushroom type produces a specific set of metabolites capable of dealing with the set of microbes that coexist in that specific environment (Dembitsky, 2010). It was reported by Bobek et al., (1991) that the consumption of a mushroom-containing diet prevented serum cholesterol increase at the end of the four week period and lowered by almost $40 \%$ as compared with control groups which have not had mushroom in their diet. Kabir and Kimura (1989) reported that dietary mushrooms have reduced the blood pressure in rats. Termitomyces robustus is called 'Ewe'meaning "expand" among the Yorubas in western Nigeria. The mushroom caps, globular at first, expands and opens out to become almost flat. It has blackish brown colour. It is the most popular edible mushroom in Nigeria but remains underutilized due to traditional believes, myths or dietary habit. Lentinus sqarrosulus,called 'erirokiro' to describe its tough, leathery texture is whitish in colour and also common in the genus Lentinus (Oso, 1976). Over the last decade, mushrooms have been studied as novel functional food, there has been many studies on the nutritional contents of different mushroom species globally, little or no work has been carried out on chemical qualities of so many species and there is a dearth of information about polyphenolic components of the species in Nigeria. The objective of this study was to investigate the chemical profile of two edible mushrooms, screen them for phytochemicals and use Reverse-Phase HPLC-DAD to quantify the polyphenols present.

\section{MATERIAL AND METHODS}

\section{Samples preparation}

The two species obtained from local markets in Nigeria were scraped and thoroughly cleaned with water to remove sand, cut into smaller pieces (both the pileus and stipes), oven dried at $60{ }^{\circ} \mathrm{C}$, then ground and sieved to give $40 \mathrm{~mm}$ mesh size powder.

\section{Preparation of extracts}

The powdered mushrooms were subjected to a cold maceration process for $72 \mathrm{~h}$ with methanol and ethanol separately to obtain the alcoholic extracts and for $24 \mathrm{~h}$ to obtain the aqueous extracts and filtered. The extracts were concentrated under vacuum and evaporated using a rotary evaporator at low temperature $\left(45^{\circ} \mathrm{C}\right)$.

\section{Phytochemical screening of the extracts}

Phytochemical screening of the methanol extracts was carried out using qualitative tests for analyses of different constituents of plant materials according to the common phytochemical methods described by Harborne (1973); Trease and Evans (1983) and Sofowora, (1993). 


\section{Chemical analyses}

Proximate composition (fat, crude fibre, and ash) was determined on dry basis by the standard method of Association of Official Analytical Chemist (AOAC, 2006), the protein content was determined using the micro-Kjedahl method ( $\mathrm{N} \mathrm{x}$ 6.25) and the carbohydrate determination by difference (AOAC, 2006). Tota dietary fibre (TDF) was determined to dried, fat-free sample according to Megazyme TDF Assay procedure, K-TDFR 05/12 (MEGAZYME INTERNATIONAL, IRELAND). The mineral elements were determined using Atomic Absorption Spectrophotometer (Pearson, 1976), vitamins by spectrophotometric methods (Biesalski et al., 1986; Benderitter et al., 1998; Okwu and Josiah, 2006), and antinutrients by titrimetry and spectrophotometric methods (Makkar and Goodchild, 1996; Day and Underwood, 1986).

\section{Determination of antibacterial activity}

The antibacterial activity of aqueous, methanolic and ethanolic extracts of the mushrooms against Staphylococcus aureus, Pseudomonas aeruginosa and Salmonella typhi bacteria was evaluated by using agar well diffusion method (Ahmad and Beg, 2001; Srinivasan et al., 2001). Plate count agar (PCA) plates were inoculated with $100 \mu \mathrm{l}$ of standardized inoculum $\left(1.5 \times 10^{8} \mathrm{CFU} / \mathrm{ml}\right)$ of each selected bacterium and spread with sterile swabs. Wells of $8 \mathrm{~mm}$ size diameter were made with sterile borer into agar plates containing the bacterial inoculum and the lower portion was sealed with a little molten agar medium. About $0.5 \mathrm{~m}$ of each of the extracts was poured into a well of inoculated plates. Chemica antibiotics, Streptomycin sulphate $\left(10 \mathrm{ugml}^{-1}\right)$ was used as a positive control which was introduced into a well instead of plant extract. The solvents; deionized water, methanol or ethanol were used as negative controls, which were introduced into the wells instead of the extracts. The plates thus prepared were left at room temperature for ten min allowing the diffusion of the extracts into the agar (Rios et al., 1988). After incubation for $24 \mathrm{~h}$ at $37{ }^{\circ} \mathrm{C}$, the plates were observed. If antibacterial activity was present on the plates, it was indicated by an inhibition zone surrounding the well containing the plant extract. The zone of inhibition was measured and expressed in millimetres.

\section{Determination of antifungal activity}

The antifungal activity of plant extracts was evaluated against food-associated fungi by using poisoned food technique. Potato dextrose agar (PDA), was weighed $(39 \mathrm{~g})$ and dispersed in a litre of deionised water sterilized at $121{ }^{\circ} \mathrm{C}$ for $15 \mathrm{~min}$, allowed to cool $\left(45^{\circ} \mathrm{C}\right)$ before pouring $(20 \mathrm{ml})$ into separated dishes. The fungi; Trichoderma rubrum and Aspergillus fumigatus were inoculated on potato dextrose agar (PDA) plates and incubated for $25^{\circ} \mathrm{C}$ for $72 \mathrm{~h}$, to obtain young, actively growing colonies of moulds. $0.2 \mathrm{ml}$ of each of the extract was mixed with $20 \mathrm{ml}$ of cooled $\left(45^{\circ} \mathrm{C}\right)$ molten PDA medium and allowed to solidify at room temperature for $30 \mathrm{~min}$. Thereafter $10 \mu \mathrm{l}$ of fungal spores in distilled water was added at the centre of the solidified PDA plates. PDA plates with $10 \mathrm{ug} \cdot \mathrm{ml}^{-1}$ of bonlate were used as positive controls. PDA plates with the solvents; deionized water, methanol or ethanol were used as negative controls (Georgi and Korting, 1991, McCutcheon et al., 1994). The inoculated plates were incubated at $25{ }^{\circ} \mathrm{C}$ and colony diameter measured and recorded after 3 days. Percentage mycelial growth inhibition (\% MGI) was calculated as given below:

$\%$ MGI = Mean dia. of fungal colony in control - Mean dia. of fungal colony in plant extract x 100

$$
\text { Mean dia. of fungal colony in control }
$$

\section{Determination of amino acid profile}

About $20 \mathrm{~g}$ of each frozen fresh mushroom sample was weighed properly and minced by using $100 \mathrm{ml}$ phosphate buffer supplemented with $2 \%$ SDS (sodium dodecyl sulfate) by using philip household blender. The homogenate was filtered through double layered cheese cloth. The filtrate was subjected to ammonium sulphate salt precipitation method at $65 \%$ saturation. The proteins were pelleted by centrifugation, concentrated by dialysis and then freez-dried for amino acid analysis. The $4.0 \mathrm{~g}$ protein isolate was hydrolyzed and evaporated in a rotary evaporator. The amino acid profile in the samples were determined using Technicon sequential multi-sample amino acid analyzer (TSM) (Benitez, 1984).

\section{Quantification of phenolic compounds by high-performance liquid chromatography with diode-arraydetection}

Reverse phase chromatographic analysis was carried out under gradient conditions using $\mathrm{C}_{18}$ column $(4.6 \mathrm{~mm} \times 150 \mathrm{~mm}$ ) packed with $5 \mu \mathrm{m}$ diameter particles; the mobile phase was water containing $2 \%$ acetic acid (A) and methanol (B), and the composition gradient was: $5 \%$ of $\mathrm{B}$ until 2 min and changed to obtain $25 \%, 40 \%, 50 \%, 60 \%, 70 \%$ and $100 \% \mathrm{~B}$ at $10,20,30,40$ 50 and 60 min, respectively, following the method described by Amaral et al.,
(2013). Each sample extract was analyzed at a concentration of $20 \mathrm{mg} / \mathrm{ml}$. The presence of eleven compounds was investigated for, T. robust and ten for $L$.

\section{Phytochemical components}

The screen of the methanol extracts of the samples showed the presence of some bioactive compounds (Tables 1). It is noteworthy that both mushrooms contained flavonoids, saponin and tannin but steroid, anthraquinone and phlobatannin were absent. Only T.robustus tested positive to alkaloid. The presence of flavonoids in both is well understood as it is in agreement with the previous literature that plants are major sources of phenolic compounds, which are synthesized as secondary metabolites during normal development in response to stress conditions, such as wounding and UV radiation among others (Sies, 1997). The alkaloids, saponnis and tannins play important roles in various antibiotics used in treating common pathogenic strains as reported by Kubmarawa et al., (2007).

\section{Chemical composition}

The result of the proximate analysis of the mushrooms on dry weight basis is presented in Table 2. The moisture content of $T$. robustus was significantly higher $(\mathrm{p} \leq 0.05)$ than that of $L$. squarrosulus. Fresh wet mushrooms have higher moisture contents which make them easily perishable. Excessive moisture content in raw materials favours the microbial growth and the decomposition of active compounds by hydrolysis. The moisture content of dried plants varies, depending on the prevailing local environment and length of storage. The protein content of $T$. robustus was significantly higher $(\mathrm{p} \leq 0.05)$ than that of $L$. squarrosulus and do not agree with the study carried out by Jose and Kayode (2009) which indicated that $L$. squarrosulus had higher protein than T. robustus Adejumo and Awosanya, (2005) however, reported a higher percentage of crude protein and moisture for Termitomyces mammiforms than Lentinus tigrinus. Percentage of crude protein obtained in this study for T. robustus was higher than $(33.8 \%)$ reported by Aletor (1995) for this same species. Oboh and Shodehinde (2009) obtained $28.60 \%$ and $24.80 \%$ for the pileus and stipes of T. robustus respectively. It has been reported that the protein content of mushrooms is affected by a number of factors. The development stage of mushroom is a significant factor affecting the protein content. In addition, the type of mushroom, the part sampled, the location as well as the substrates affect protein content (Barroset al., 2007; Kalmiş et al., 2011). The whole mushrooms (pileus and stipes) were analysed in this work. Proteins are the building blocks of life. The body needs protein to repair and maintain itself. Since it was present in appreciable quantity in both mushrooms, nutritional power of these fungi as protein supplements cannot be ignored

Both mushrooms contained higher ash, than crude fat, the same trend obtained by Oboh and Shodehinde (2009), and the ash content of the two compared favorably with percentage ash of $7.8 \pm 0.6,8.3 \pm 0.0$, and $7.3 \pm 0.3$ reported earlier for Ganoderma spp., Omphalotus olearius and Hebeloma mesophaeum respectively (Aremu et al., 2009), also with some other vegetables such as Occimumgraticimum (8.00\%) and Hibiscus esculentus (8.00\%) (Akindahunsi and Salawu, 2005). High ash content is an indication of high mineral content, a reflection of the mineral contents preserved in the food materials (Antia $\boldsymbol{e t}$ al., 2006). Mineral elements are essential for tissue functioning and a necessity in daily requirement for human nutrition. The result therefore suggests a high deposit of mineral elements in the mushrooms. T. robustus has higher crude fat than that of $L$. squarrosulus, the values obtained for the two however fell within the range of percentage crude fat obtained for some wild mushrooms in Turkey, which was $1.40 \pm 3.00-10.58 \pm 0.30$ for Cantharellus cibarius Fr and Lycoperdon perlatum Pers., respectively (Ahmet et al., 2009). Dietary fats help in absorbing and retaining flavours, thus, increase the palatability of food (Antia et al., 2006). Although, a diet providing 1-2\% of its caloric of energy as fat is said to be sufficient to human beings; as excess fat consumption is implicated in certain cardiovascular disorders such as atherosclerosis, cancer and aging (Antia et al., 2006), Ononugbu (2002) reported that vegetable fats and oil lower blood lipids thereby reducing occurrence of disease associated with damage of coronary artery. Plant lipids are useful as essential oils, spice, oleoresins and natural food colors and have been developed to products that work with diverse requirements, as culinary, medicinal and cosmetics (Yadav and Tyagi, 2006).

The L. squarrosulus in this study had significantly higher crude fibre than T.robustus, both had higher values than percentage crude fibre of $3.5 \pm 0.2,2.8 \pm$ 0.5 and $3.2 \pm 1.0$ reported for Ganoderma spp., Omphalotus olearius and Hebeloma mesophaeum respectively by Aremu et al. (2009). The total dietary fibre values were higher in both mushrooms than crude fibre as expected. Carbohydrate by difference of $L$. squarrosulus was significantly higher $(\mathrm{p} \leq 0.05)$ than that of $T$. robustus, the lower carbohydrate level can not affect energy contribution due to the compensation from higher protein values in T.robustus Therefore, there was no significant differences in calorific values of the two mushrooms. Carbohydrates are one such group of carbon compounds, which are essential to life. Almost all organisms use carbohydrates to exploit their rich supply of potential energy to maintain life. Calculated energy values of the T.robustus and L. squarrosulus, here were found to be lower than previous data 
obtained for eight edible wild mushrooms in Turkey which varied from 367.88 $\mathrm{kcal} / 100 \mathrm{~g}$ to $450.20 \mathrm{kcal} / 100 \mathrm{~g}$ on dry matter basis (Ahmet et al., 2009).

The macro elements; calcium, phosphorus, potassium, sodium and magnesium as well as the trace elements iron, copper and zinc were all in higher concentrations in $T$. robusts than $L$. squarrosulus. Lead, mercury and manganese were not detected in any of the mushrooms. Calcium is a major factor sustaining strong bones; it plays a part in blood clotting, muscle contraction and relaxation Muhsin, (2006) reported Ca levels of $124 \mathrm{ppm}$ in $1 \mathrm{~g}$ of dried Lactarius delicious, calcium and phosphorus are the minerals are abundant in the the bones. Agaricus bisporus was found to contain $110 \mathrm{mg} / 100 \mathrm{~g}$ phosphorus (Peter et al. 2012). Potassium is the most abundant element in both mushrooms, edible wild mushroom species have an average potassium content of $34,350 \mathrm{mg} / \mathrm{kg}$ on a dry basis, making them an important and valuable potassium source for the human diet (Kalmiş et al., 2011). Studies have revealed that the potassium concentration of mushrooms is relatively constant (Vetter, 1994). The sodium content of Tricholoma terreum was reported as $92.6-325 \mathrm{mg} / \mathrm{kg}$ on a dry basis (Demirbaş, 2001; Vetter, 2003; Kalmiş et al., 2011),Vinhal,et al., 2012 also reported 255.34 and $613.03 \mathrm{mg} / 100 \mathrm{~g}$ for sodium and potassium respectively in Agaricus sylvaticus. Sodium and potassium are important intracellular and extracellular cations respectively. Values obtained for magnesium in both mushrooms were lower than what was reported by Ezeibekwe, et al., (2009) for Plerotus tuberregium $(0.24 \%)$ and Auricularia auricular $(0.36 \%)$. Magnesium functions as a co-factor of many enzymes involved in energy metabolism, protein synthesis, RNA and DNA synthesis. Ahmet, (2009) obtained the range $30.20 \pm 2.90$ $550.00 \pm 15.00 \mathrm{in} \mathrm{mg/kg}$ for Fe in Ramaria flava and Lycoperdon perlatum Pers and $15.20 \pm 1.10-330.00 \pm 91$ for $\mathrm{Cu}$ in Craterellus cornucopioides and Armillaria mellea respectively. Iron plays important role in the formation of haemoglobin (Latunde-Dada, 2006) and hence recommended for anaemic convalescence, copper is an essential micronutrient which functions as a biocatalyst required for body pigmentation in addition to iron. The trace metal contents of mushrooms are related to species of mushroom, collecting site of the sample, age of fruiting bodies and mycelium, as well as distance from sources of pollution (Kalac et al., 1991). They are mainly affected by acidic and organic matter contents of the soil. This may be responsible for the wide difference in the $\mathrm{Zn}$ contents of the two mushrooms in this study. $\mathrm{Zn}$ content of $370.00 \mathrm{mg} / \mathrm{kg}$ dry weight was found in R. flava and $47.00 \mathrm{mg} / \mathrm{kg}$ dry weight in L. perlatum (Ahmet, 2009). Zinc is widespread among living organisms due to its biological significance and mushrooms are known as zinc accumulators (Mendil, 2004) Manganese is part of enzyme involved in urea formation, pyruvate metabolism and the galactotransferase of connective tissue biosynthesis (Chandra, 1999), but it was not detected in any of the mushrooms under study.

Vitamins A (carotene equivalent) and tocopherol $\mathrm{E}$ were detected in the two mushrooms investigated (Table 2). Vitamin A was found in significantly higher ( $\mathrm{p} \leq 0.05$ ) concentration in $T$. robustus but $\mathrm{E}$ in lower concentration than $L$ squarrosulus. Vitamin A is involved in immune function, vision, reproduction, and cellular communication (Johnson and Russell, 2010; Solomons, 2006). According to Mushroom and Health Report, common Agaricus bisporus contained $13.0 \mu \mathrm{g} / 100$ Beta-carotene equivalent vitamin A (2 $\mu \mathrm{g}$ RE) (Peter $\boldsymbol{e} t$ al., 2012) and Agaricus sylvaticus was also found to contain $\alpha$-tocopherol of $0.020 \mathrm{mg} / 100 \mathrm{~g}$ (Vinhal et al., 2012).Vitamin $\mathrm{E}$ is an important vitamin required for the proper function of many organs in the body. It is also an antioxidant. This means it helps to slow down processes that damage cells (Yun-Zhong et al., 2002). Water soluble vitamins; thiamine $\left(B_{1}\right)$ and ascorbic acid $(C)$ were also detected in the two mushrooms in appreciable quantities compared with vitamin $\mathrm{C}$ of $12.65 \mathrm{mg} / 100 \mathrm{~g}$ reported for Agaricus sylvaticus (Vinhal et al., 2012) and $\mathrm{B}_{1}$ of $0.025 \mathrm{mg} / 100 \mathrm{~g}$ fresh weight found in Agaricus bisporus (Peter et al. 2012). All B vitamins help the body convert food (carbohydrates) into fuel (glucose), which is used to produce energy and also help the body metabolize fats and protein.

Tannin, oxalate and phytates were found in higher concentrations in T.robustus than $L$. Squarrosulus. phytate and oxalate concentrations obtained in the present study were lower compared to phytic acid content range of $160 \mathrm{mg} / 100 \mathrm{~g}$ in $T$. robustus to $360 \mathrm{mg} / 100 \mathrm{~g}$ in C. cyathiformis with a CV of $28.4 \%$ and oxalate content range of $80 \mathrm{mg} / 100 \mathrm{~g}$ in T. robustus to $220 \mathrm{mg} / 100 \mathrm{~g}$ in A. auricula with a CV of $3.8 \%$ obtained by Aletor (1995) from a research on some edible tropical species of mushrooms. Antinutrients are substances that bind enzymes or nutrients and inhibit the absorption of the nutrients. Tannins even at low levels inhibit digestive enzymes activities making their presence in food undesirable from a nutritional point of view (El-Adawy et al., 2000). However, tannins have been shown to give substantial protection against cancer of the lungs and stomach when ingested orally (Yavelow et al., 1983). Tannin and other phenols may play a role in fighting tooth decay by inhibiting the growth of bacteria that cause tooth decay (Moles and Waterman, 1985). Phytates, like tannins have also been found to interact with digestive processes in a beneficial way, slowing down the absorption of sugars and regulate insulin levels when present in small amounts in food, this is beneficial in the prevention and treatment of diabetes and hyperlipidemia (high blood fats) and phytic acid also acts as antioxidant
(Hawkins et al., 1993; Phillippy and Graf, 1997). Many researchers believe that dietary restriction cannot significantly reduce risk of stone formation because dietary oxalate was found to accounts for only $10-15 \%$ of the oxalate that was detected in the urine of individuals who formed calcium oxalate stones, (Assimos and Holmes, 2000; Curhan, 1999; Parivar et al., 1996; Hanson et al., 1989). This result therefore suggests that the mushooms are safe for consumption.

\section{Amino acid composition of the mushrooms}

The result of the amino acid analysis of the protein isolates from the two mushrooms is presented in Table 3. All the essential and non-essential amino acids detected were in significantly higher $(\mathrm{p} \leq 0.05)$ concentrations in T.robustus than L.squarrosulus except leucine which was the highest amino acid found in $L$. squarrosulus. Both mushrooms contained most of the essential amino acids in substantial quantities and even exceeded protein requirement pattern (FAO/WHO, 1991) in some cases. Aspartic acid $(0.37 \%)$, arginine $(0.21 \%)$, alanine $(0.09 \%)$, proline $(0.06 \%)$, and tyrosine $(0.19 \%)$ content obtained for $L$. squarrosulus by Sharma et al., (2012) were lower than the quantities found in the same species in this study. Glutamic acid was the highest amino acid in T.robustus in conformity with the work of Nakalembe and Kabasa, (2013) on Termitomyces species, followed by leucine while glutamic acid was second to leucine in L. squarrosulus contrary to the findings of Dembitsky et al., (2010) that aspartic acid dominate other amino acids in Boletus species. The most important benefit of leucine is its capacity to maintain blood sugar level. It can also help in producing growth hormones, healing bones and skin, sustaining nitrogen balance and maintaining mental ability (Anthony et al., 2002). Overall, the amino acid profiles were similar in both mushroom species though they belong to different families, also similar to the profile obtained from P. leurotus species except for norvaline and tryptophan found in small amounts in $P$. ostreatus and P. Sajorcaju (Pornariya and Kanok-Orn, 2009).

\section{Phenolic compounds in the mushrooms}

HPLC fingerprinting of $T$. robustus extract revealed the presence of the gallic acid $\left(t_{R}=11.57\right.$ min; peak 1$)$, catechin $\left(t_{R}=16.09\right.$ min; peak 2$)$, chlorogenic acid $\left(t_{R}=23.51\right.$ min; peak 3), caffeic acid $\left(t_{R}=25.06\right.$ min; peak 4), ellagic acid $\left(t_{R}=\right.$ 32.14 min; peak 5), epicatechin $\left(t_{R}=35.98 \mathrm{~min}\right.$; peak 6$)$, rutin $\left(t_{R}=38.25\right.$ min; peak 7), isoquercitrin $\left(t_{R}=42.56\right.$ min; peak 8$)$, quercetin $\left(t_{R}=45.01 \mathrm{~min}\right.$; peak 9), quercitrin $\left(t_{R}=48.93\right.$ min; peak 10) and kaempferol $\left(t_{R}=54.39\right.$ min; peak 11) (Fig. 1 and Table 4) while that of Lentinus squarrosulus extract revealed the presence of the gallic acid $\left(t_{R}=10.52\right.$ min; peak 1$)$, catechin $\left(t_{R}=16.03\right.$ min; peak 2), chlorogenic acid $\left(t_{R}=22.53 \mathrm{~min}\right.$; peak 3$)$, caffeic acid $\left(t_{R}=25.11 \mathrm{~min}\right.$; peak 4), ellagic acid $\left(t_{R}=32.15\right.$ min; peak 5), epicatechin $\left(t_{R}=35.09\right.$ min; peak $6)$, rutin $\left(t_{R}=39.64 \mathrm{~min}\right.$; peak 7$)$, isoquercitrin $\left(t_{R}=42.95\right.$ min; peak 8), quercitrin $\left(t_{R}=45.10\right.$ min; peak 9) and quercetin $\left(t_{R}=48.72\right.$ min; peak 10) (Fig. 2 and Table 4).

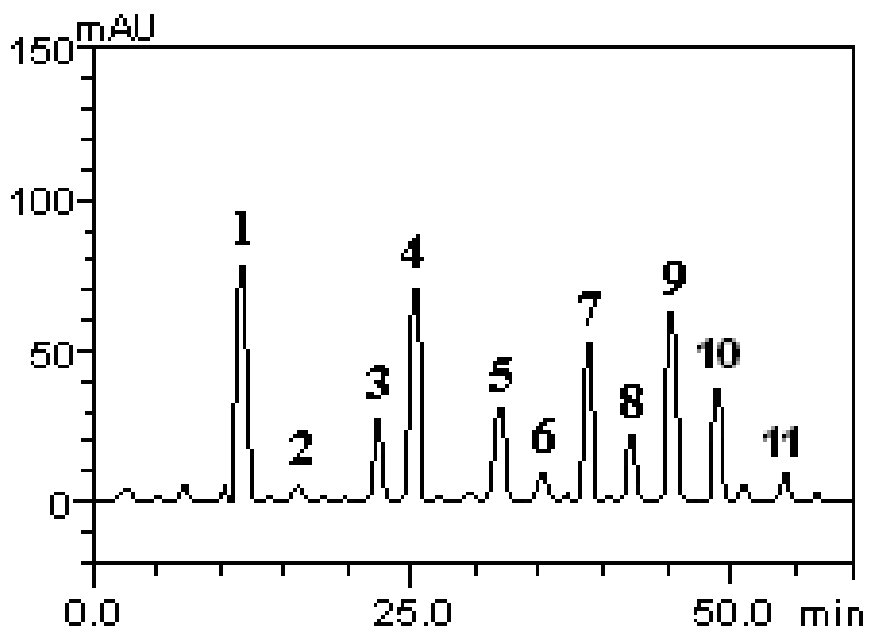

Figure 1 Reverse-phase high performance liquid chromatography profile of Termitomyces robustus extract. Gallic acid (peak 1), catechin (peak 2), chlorogenic acid (peak 3), caffeic acid (peak 4), ellagic acid (peak 5), epicatechin (peak 6), rutin (peak 7), isoquercitrin (peak 8), quercitrin (peak 9), quercetin (peak 10) and kaempferol (peak 11). 


\section{mAU}

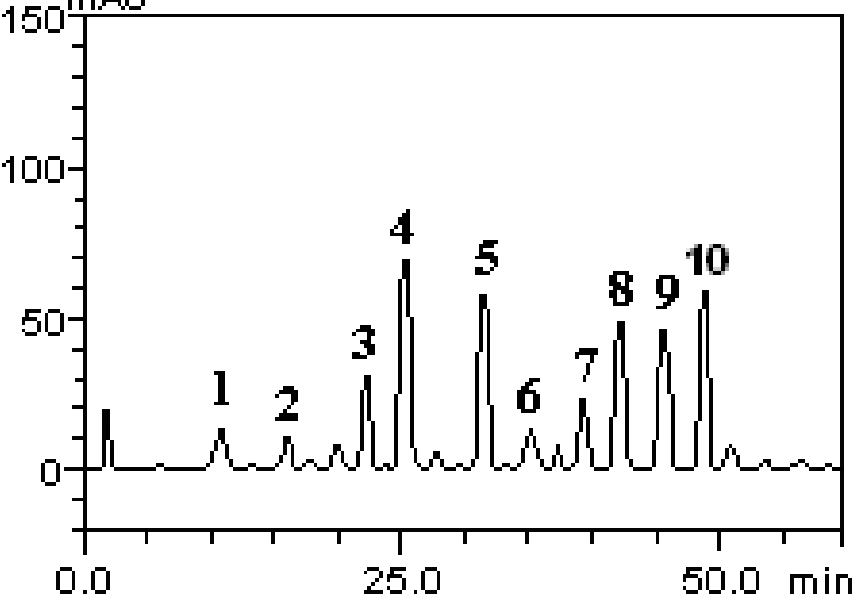

Figure 2 Reverse-phase high performance liquid chromatography profile of $L$ squarrosulus extract. Gallic acid (peak 1), catechin (peak 2), chlorogenic acid (peak 3), caffeic acid (peak 4), ellagic acid (peak 5), epicatechin (peak 6), rutin (peak 7), isoquercitrin (peak 8), quercitrin (peak 9) and quercetin (peak 10).

Gallic acid, caffeic acid, rutin, quercetin and isoquercitrin were present in both at different concentrations. Gallic acid, a benzoic acid derivative and caffeic acid, a cinnamic acid derivative belong to a phenolic acid class. Gallic acid concentration is significantly higher $(\mathrm{p} \leq 0.05)$ in $T$. robust than $L$. squarrosulus, ellagic and chlorogenic acids are significantly higher $(\mathrm{p} \leq 0.05)$ in $L$. squarrosulus but no significant difference in the caffeic acid concentrations of the two mushrooms. According to the studies published by Kaur et al., (2009) and Rasool et al., (2010), gallic acid possesses significant antioxidant activity and may protect the liver from the harmful effects of free radicals that are formed as a result of various metabolic processes in the body and inhibit the growth of human prostate cancer cells. Caffeic acid (3, 4-Dihydroxycinnamic Acid) is a naturally occurring substance found in many plants, including coffee beans but is entirely unrelated to caffeine and shares no stimulant activity with that of caffeine. Ellagic acid is a type of chemical found in a variety of fruits, berries and plants. Foods high in ellagic acid include raspberries, pomegranates, blackberries, pecans and walnuts. Structurally, chlorogenic acid is a combination of two molecules. It is a caffeic acid molecule bound to a quinic acid moiety, the combination is referred to as chlorogenic acid, and all three molecules can be bioactive after chlorogenic acid ingestion (Jin et al., 2012). Catechin, epicatechin, isoquercitrin and quercetin were in higher concentrations in L.squarrosulus, while rutin and quercitrin in lower concentrations than in T.robustus. Quercetin and kaempferol are in flavonol 3-O-glycosides class, quercetin, is a flavonol occurring in fruit and vegetable in food component with proven beneficial impact on health. Kaempferol was presnt in T. robustus but not found in L.squarrosulus. Isoquercitrin (2-(3, 4-dihydroxyphenyl)-5, 7-dihydroxy3-oxy-chromen-4-one) is quercetin 3-glucoside, while quercetin, is present in many plants, but for practical purposes it is derived from rutin (quercetin-3-Orhamnoglucoside). Quercetin is one of the most potent antioxidants among polyphenols and has also been demonstrated to display the antiviral, antibacterial, anticarcinogenic and antiinflammatory effects (Walle, 2004; Naidu et al., 2012). Chemically, quercetin is closely related to rutin and quercitrin, two other flavonoids. Quercetin lacks a sugar molecule that is attached to these other flavonoids. When rutin and quercitrin are digested, intestinal bacteria remove the sugar molecule.

\section{Antimicrobial Activities of Mushrooms}

The antibacterial activities of aqueous solutions and alcoholic extracts of $T$. robustus (ewe) and L. squarrosulus (erirokiro) at concentrations $0.05 \mathrm{~g} / \mathrm{ml}$ are presented in Figures 3- 5 with Streptomycin sulphate used as positive controls for antibacterial. None of the extracts showed activity against $P$. aeruginosa except ethanol extract of $L$. squarrosulus. $S$. typhi was also susceptible to an aqueous and methanol extracts of $L$. squarrosulus. Only alcoholic extracts of $T$. robustus and $L$. Squarrosulus showed inhibitory activities against $S$. aureus. The antimicrobial activities of the extracts against $P$. aeruginosa and $S$. typhi were similar, methanol extracts showed more effectiveness than ethanol, this may be due to the fact that they are gram negative organisms and they are physiologically related, this was noticed to be related to the work of Abosi and Raseroka (2003).The extracts showed better antimicrobial activities against $S$. aureus, this may be linked with the composition of their cell wall as they are gram positive. Aqueous extract of $L$. squarrosulus was active against $S$. typhi but that of $T$. robustus was not. Both mushrooms showed activities against $S$. aureus but $T$. robustus showed no activity against $P$. aeruginosa and $S$. typhi. Generally, all the extracts of the two mushrooms exhibited weak antibacterial activities compared with the chemical antibiotics; streptomycin sulphate. The antifungal activities of the mushrooms against the selected pathogens are presented in Figures $6-7$. These present the percentage mycelia growth inhibition of the sample extracts against filamentous fungi, T. rubrum and A. fumigatus. The results revealed methanol extracts of the samples had no inhibitory effects against any of the fungi in contrast with bonlate which was used as the positive control. A fumigatus showed higher susceptibility to aqueous and ethanol extracts. The aqueous and ethanol extracts of the mushrooms demostrated quite appreciable antifungal activities when compared with bonlate. The high susceptibility displayed by the fungi to the ethanolic extracts of the samples suggests that the ethanolic extracts may be developed as antifungal drugs to treat infections caused by these organisms and preservatives for stored products like grains.

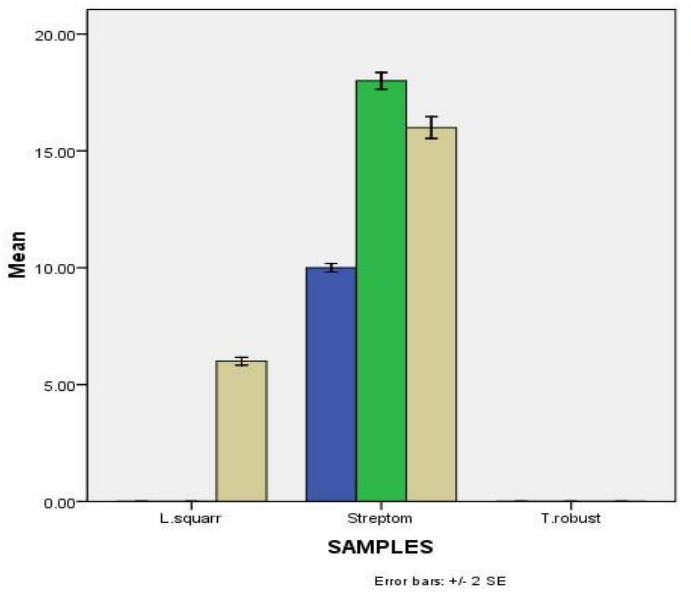

RAq.P.aeruginosa MeOH.P.aeruginosa

Figure 3 Antibacterial activities of extracts $\left(0.05 \mathrm{~g} / \mathrm{cm}^{3}\right)$ with Streptomycin sulphate as positive control against Pseudomonas aeruginosa at $24 \mathrm{~h}$ incubation

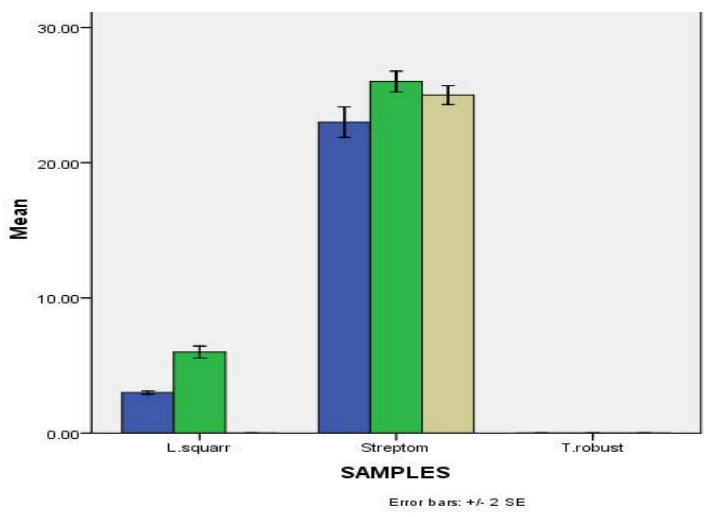

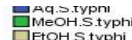

Figure 4 Antibacterial activities of extracts $\left(0.05 \mathrm{~g} / \mathrm{cm}^{3}\right)$ with Streptomycin sulphate as positive control against Salmonella typhii at $24 \mathrm{~h}$ incubation

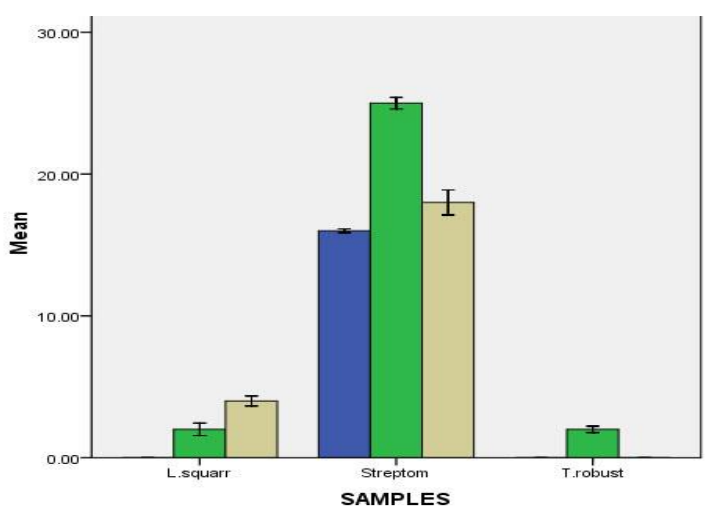

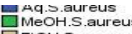
Emror bars: +1.2 SE

Figure 5 Antibacterial activities of extracts $\left(0.05 \mathrm{~g} / \mathrm{cm}^{3}\right)$ with Streptomycin sulphate as positive control against Staphylococcus aureus at $24 \mathrm{~h}$ incubation 


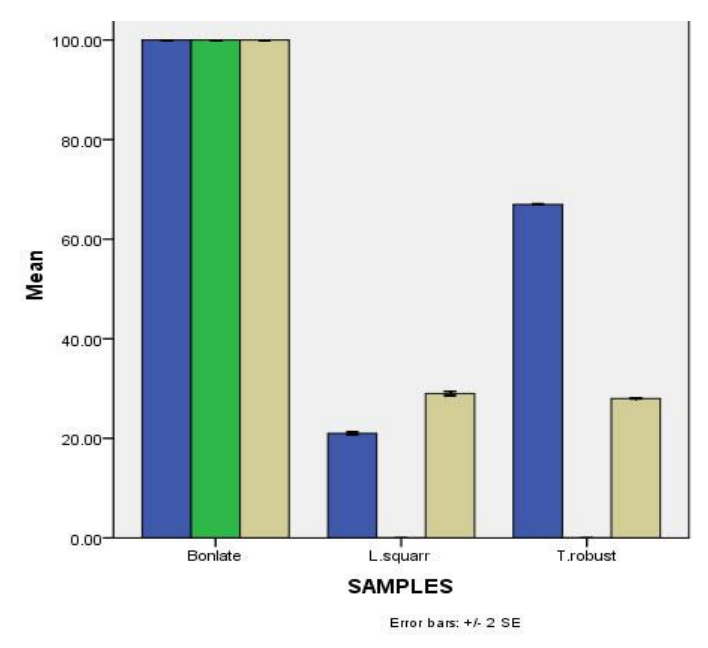

Figure 6 Antifungal activities of extracts $\left(0.05 \mathrm{~g} / \mathrm{cm}^{3}\right)$ with bonlate as positive control against Trichoderma rubum at $24 \mathrm{~h}$ incubation

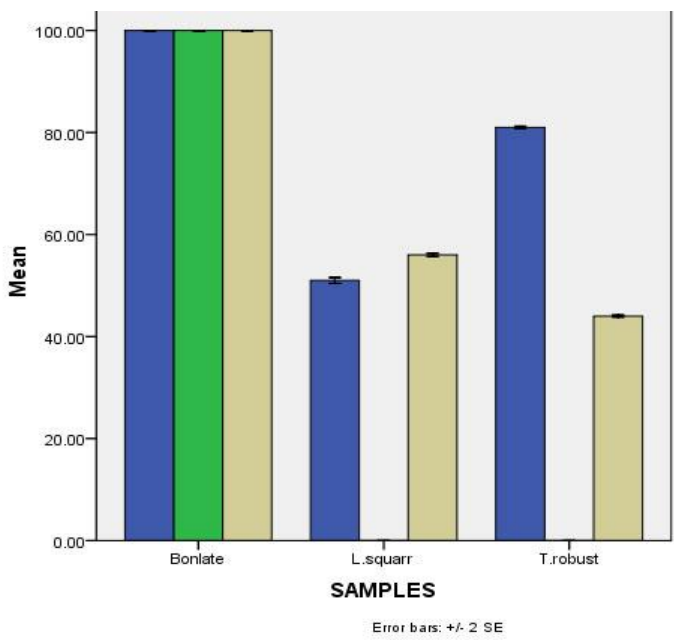

Figure 7 Antifungal activities of extracts $\left(0.05 \mathrm{~g} / \mathrm{cm}^{3}\right)$ with bonlate as positive control against Aspetrillus fumigatus at $72 \mathrm{~h}$ incubation

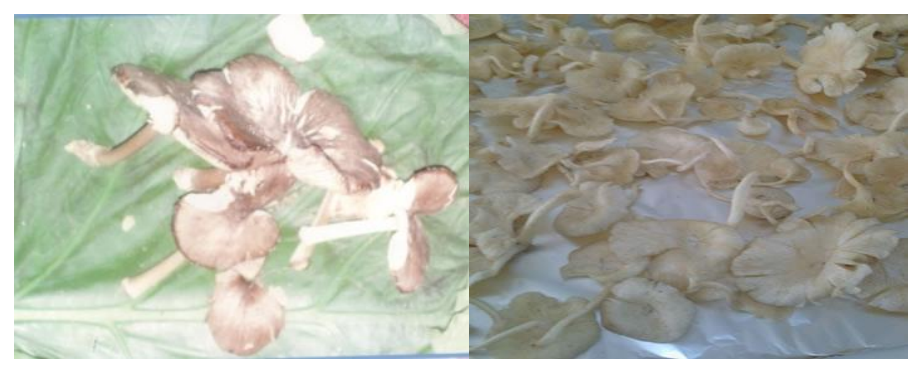

Figure $\mathbf{8}$ Termitomyces robustus

Figure 9 Lentinus squarrosulus

Table 1 Phytochemicals screening result

\begin{tabular}{lcc}
\hline \multirow{2}{*}{ Phytochemicals } & \multicolumn{2}{c}{ Mushrooms species } \\
\cline { 2 - 3 } Alkaloid & T.robustus & L. squarrosulus \\
Saponin & + & - \\
Tannin & + & + \\
Flavonoid & + & + \\
Steroid & + & + \\
Terpenoid & - & - \\
Anthraquinone & + & + \\
Phlobatannin & - & - \\
\hline
\end{tabular}

= Absent

$+\quad=$ present
Table 2 Chemical compositions of the mushrooms

Mushroom species

Compositions

T. robustus $\quad$ L. squarrosulus
.

Moisture

Crude protein

$11.03 \pm 0.22 \mathrm{~b}$

$7.22 \pm 0.07 \mathrm{a}$

$42.77 \pm 0.57 \mathrm{~b} \quad 31.24 \pm 0.02 \mathrm{a}$

Ash

$10.45 \pm 0.43 \mathrm{~b}$

$7.07 \pm 0.04 \mathrm{a}$

Crude fibre

$4.07 \pm 0.18 \mathrm{a}$

$9.48 \pm 0.04 \mathrm{~b}$

Crude fat

Carbohydrate

$6.76 \pm 0.22 b$

$3.71 \pm 0.16 \mathrm{a}$

Calorific Value (kcal)

$24.90 \pm 0.11 \mathrm{a}$

$41.27 \pm 0.19 \mathrm{~b}$

$331.55 \pm 3.41 \mathrm{a}$

$342.35 \pm 3.09 \mathrm{a}$

Total dietary fibre

Sodium (mg/100g)

Potassium (mg/100g)

$10.21 \pm 0.00 \mathrm{a}$

$11.68 \pm 0.00 \mathrm{~b}$

$270.00 \pm 0.08 \mathrm{~b}$

$200.00 \pm 0.03 \mathrm{a}$

Calcium (mg/100g)

$1460.00 \pm 0.11 \mathrm{~b}$

$60.00 \pm 0.01 b$

$800.00 \pm 0.33 \mathrm{a}$

Magnesium (mg/100g)

$106.00 \pm 0.05 b$

$40.00 \pm 0.03 \mathrm{a}$

Zinc (mg/100g)

Copper (mg/100g)

$81.00 \pm 0.03 \mathrm{~b}$

$98.00 \pm 0.04 \mathrm{a}$

$0.90 \pm 0.02 \mathrm{~b}$

$19.00 \pm 0.02 \mathrm{a}$

Iron (mg/100g)

Phosphorus(mg/100g)

Manganese (mg/100g)

Lead (mg/100g)

Mercury (mg/100g)

Vitamin A( $\beta$-Carotene

Equivalent, $\mu \mathrm{g} / \mathrm{g}$ )

Thiamine $(\mu \mathrm{g} / \mathrm{g})$

Ascorbic acid $(\mu \mathrm{g} / \mathrm{g})$

$2.70 \pm 0.01 \mathrm{~b}$

$0.20 \pm 0.02 \mathrm{a}$

$30.80 \pm 0.01 b$

$0.40 \pm 0.01 \mathrm{a}$

ND

$22.50 \pm 0.02 \mathrm{a}$

ND

ND

ND

ND

ND

$13.33 \pm 0.02 b$

$12.80 \pm 0.01 \mathrm{a}$

$324.23 \pm 0.02 \mathrm{a}$

$328.42 \pm 0.00 \mathrm{~b}$

$14.22 \pm 0.01 \mathrm{~b}$

$11.61 \pm 0.00 \mathrm{a}$

Tocopherol $(\mu \mathrm{g} / \mathrm{g})$

$383.12 \pm 0.02 \mathrm{a}$

$1191.39 \pm 0.01 b$

Tannin (mg/g)

Oxalate $(\mathrm{mg} / \mathrm{g})$

$7.40 \pm 0.14 b$

$3.25 \pm 0.80 \mathrm{a}$

$1.71 \pm 0.07 b$

$1.53 \pm 0.00 \mathrm{ab}$

Phytate (mg/g)

$1.94 \pm 0.05 b$

$1.48 \pm 0.06 \mathrm{a}$

Values represent means of triplicate readings \pm S.D. Values with the same superscript along the row are not significantly different $(\mathrm{p} \geq 0.05)$.

Table 3 Amino acid composition

\begin{tabular}{lccc}
\hline & \multicolumn{2}{c}{$\begin{array}{c}\text { Concentrations in the } \\
\text { Mushroom species }(\mathrm{g} / 100 \mathrm{~g})\end{array}$} \\
\cline { 2 - 4 } & T.robustus & L.squarrosulus & *RP \% \\
\hline Histidine & 2.33 & 1.96 & 1.9 \\
Isoleucine & 3.77 & 2.85 & 2.8 \\
Leucine & 9.07 & 16.99 & 6.6 \\
Lysine & 5.02 & 2.67 & 5.8 \\
Methionine & 1.28 & 0.73 & \\
Phenylalanine & 4.39 & 3.37 & $6.3 \mathrm{a}$ \\
Threonine & 3.48 & 2.53 & 3.4 \\
Valine & 3.91 & 3.01 & 3.5 \\
Arginine & 5.01 & 3.62 & \\
Aspartic acid & 8.62 & 7.17 & \\
Serine & 2.39 & 2.03 & \\
Glutamic acid & 10.98 & 10.00 & \\
Proline & 2.75 & 2.14 & \\
Glycine & 4.33 & 3.00 & \\
Alanine & 3.33 & 3.23 & \\
Cysteine & 0.99 & 0.60 & \\
Tryosine & 3.02 & 2.06 & \\
\hline a & & & \\
\hline
\end{tabular}

$\mathrm{a}=$ Phenylalanin with Tyrosine, $\mathrm{b}=$ Cystein with Methionine, ${ }^{*} R P \%=$ Requirement Pattern in \% protein (FAO/WHO 1991) 
Table 4 Phenolic compounds in the mushrooms

\begin{tabular}{lcc}
\hline \multirow{2}{*}{ Phenolic compounds } & Concentrations in the Mushroom species (mg/g) \\
\cline { 2 - 3 } & $47.91 \pm 0.02 \mathrm{~b}$ & L.squarrosulus \\
\hline Gallic acid & $18.47 \pm 0.01 \mathrm{a}$ & $7.93 \pm 0.02 \mathrm{a}$ \\
Chlorogenic acid & $41.80 \pm 0.05 \mathrm{a}$ & $20.61 \pm 0.03 \mathrm{~b}$ \\
Caffeic acid & $20.52 \pm 0.02 \mathrm{a}$ & $41.09 \pm 0.02 \mathrm{a}$ \\
Ellagic acid & $3.64 \pm 0.01 \mathrm{a}$ & $38.67 \pm 0.02 \mathrm{~b}$ \\
Catechin & $7.28 \pm 0.01 \mathrm{a}$ & $6.58 \pm 0.01 \mathrm{~b}$ \\
Epicatechin & $36.94 \pm 0.01 \mathrm{~b}$ & $8.23 \pm 0.01 \mathrm{~b}$ \\
Rutin & $13.85 \pm 0.02 \mathrm{a}$ & $15.34 \pm 0.01 \mathrm{a}$ \\
Isoquercitrin & $40.96 \pm 0.02 \mathrm{~b}$ & $30.71 \pm 0.02 \mathrm{~b}$ \\
Quercitrin & $26.11 \pm 0.01 \mathrm{a}$ & $29.55 \pm 0.03 \mathrm{a}$ \\
Quercetin & $7.83 \pm 0.03 \mathrm{~b}$ & $38.96 \pm 0.01 \mathrm{~b}$ \\
Kaempferol & & $0 \pm 0.00 \mathrm{a}$ \\
\hline Values represent mean
\end{tabular}

Values represent means of triplicate readings \pm S.D. Values with the same superscript along the row are not significantly different $(\mathrm{p} \geq 0.05)$.

\section{CONCLUSION}

The nutritional quality of the mushrooms in terms of protein, vitamins and mineral elements revealed their potentials as nutritious foods. The reported health benefits of Termitomyces robustus and Lentinus squarrosulus could be related to the presence of their natural phytochemicals like phenolic acids, flavonoids, amino acids and vitamins which are known to possess antioxidant properties. They could be developed as functional foods for the prevention of degenerative diseases. Increase consumption of these mushrooms would seem to be of great health benefit. Large scale cultivation should therefore be encouraged not only for the nutraceutical potentials but food security as well as economic sustainability. Research into favourable conditions to domesticate the above mentioned mushrooms and the numerous wild species as well as government policies to promote production and trade are essential in order to maximise the poential of mushrooms as valuable natural resources for food, medicine and biochemicals for industrial purpose.

Acknowledgment: I am grateful to Mrs O. O. Crown, Mrs Oseni and Mr M. O. Oguntokun,, all in Federal University of Technology, Akure, ondo State, Nigeria for their assistance throughout the period of this study and every one, who in one way or the other has contributed to the successful completion of this work.

\section{REFERENCES}

ABOSI, A. O., RASEROKA, B. H. (2003): In vivo antimalarial activity of Vernonia amygdalina. British journal of biomedical science. 60 (2): 89 - 91.

ADEJUMO, T. O., AWOSANYA, O. B. 2005. Proximate and mineral composition of four edible mushroom species from South Western Nigeria. African Journal of Biotechnology, 4(10), 1084-1088.

AGRAHAR-MURUGKAR, D., SUBBULAKSHMI, G. 2005. Nutritional value of edible wild mushrooms collected from the Khasi hills Meghalaya. Food Chemistry, 89, 599-603. http://dx.doi.org/10.1016/j.foodchem.2004.03.042

AHMAD, I., BEG, A. J. 2001. Antimicrobial and phytochemical studies on 45 Indian medicinal plants against multidrug resistant human pathogens. Journal of Ethnopharmacology, 74 (2), 113-123. http://dx.doi.org /doi:10.1016/S03788741(00)00335-4

AHMET, C. Ö., ERTUĞRUL, S. 2009. Nutritional composition of some wild edible mushrooms. Turkish Journal of Biochemistry, 34 (1), 25-31.

AKINDAHUNSI, A. A., SALAWU, S. O. 2005. Phytochemical screening and nutrient-antinutrient composition of selected tropical green leafy vegetables. African Journal of Biotechnology, 4(6), 497-501.

ALETOR, V. A. 1995. Compositional studies on edible tropical species of mushrooms. Food Chemistry, 54(3), 265-268. http://dx.doi.org /10.1016/03088146(95)00044-J

AMARAL, G. P., CARVALHO, N. R., BARCELOS, R. P., DOBRACHINSKI, F., PORTELLA, R. L., DA SILVA, M., LUGOKENSKI, T. H., DIAS, G. R. M., LUZ, S. C. A., BOligON, A. A., ATHAYDE, M. L., VIlletTI, M. A., SOARES, F. A. A., FACHINETTO R. 2013. Protective action of ethanolic extract of Rosmarinus officinalis L. in gastric ulcer prevention induced by ethanol in rats. Food and Chemical Toxicology, 55, 48-55. http://dx.doi.org/10.1016/j.fct.2012.12.038

ANTHONY, J. C., LANG, C. H., CROZIER, S. J., ANTHONY, T. G., MACLEAN, D. A., KIMBALL, S. R., JEFFERSON, L. S. 2002. Contribution of insulin to the translational control of protein synthesis in skeletal muscle by leucine. American Journal of Physiology, Endocrinology and metabolism, 282(5), E1092-101.http://dx.doi.org/10.1152/ajpendo.00208.2001

ANTIA, B. S., AKPAN, E. J., OKON, P. A., UMOREN, I. U. 2006. Nutritive and anti- nutritive evaluation of sweet potatoes (Ipomoea batatas) leaves. Pakistan Journal of Nutrition, 5(2), 166-168.

http://dx.doi.org/10.3923/pjn.2006.166.168

AREMU, M. O., BASU, S. K., GYAR, S. D., GOYAL, A., BHOWMIK, P. K. DATTA B. 2009. Proximate composition and functional properties of mushroom flours from Ganoderma spp., Omphalotus olearius (DC.) sing. and Hebeloma mesophaeum (pers.) quél. used in Nasarawa State, Nigeria. Malaysian Journal of Nutrition, 15(2), $233-241$.

ASSIMOS, D. G., HOLMES, R. P. 2000. Role of diet in the therapy of urolithiasis. The Urologic clinics of North America, 27(2), 255-68.

AOAC. 2006. Official Method ofAnalysis of the Association of Official Analytical Chemist W. Horwitz editor, eighteen edition, Washington; D. C.

BARROS, L., BAPTISTA, P., CORREIA, D. M., CASAL, S., OLIVERIA, B., FERREIRA, I. C. F. R. 2007. Fatty acid and sugar compositions and nutritional value of five wild edible mushrooms from Northeast Portugal. Food Chemistry, 105(1), 140-145. http://dx.doi.org/ 10.1016/j.foodchem.2007.03.052

BENDERITTER, M., MAUPOLI, V., VERGELY, C., DALLOZ, F. B., ROCHETTE, L. 1998. Studies by electron paramagnetic resonance of the important of iron in hydroxyl scavengening properties of ascorbic acid in plasma: effect of iron chelator. Fundamental andclinical pharmacology, 12(5), 510-516. BENITEZ, L. V. 1984. Amino acid and fatty acid profiles in aquaculture nutrition studies. In: S. S. De Silva (ed.). Fish Nutrition Research in Asia. (Proceedings of the third Asian fish nutrition network meeting, Asian Fisheries Society), Manila Philippines: Asian Fish Society special publication, 4, 23 - 35. BIESALSKI, H., GREIFF, H., BRODDA, K., HAFNER, G., BÄSSLER, K. H. 1986. Rapid determination of vitamin A (retinol) and vitamin E (alphatocopherol) in human serum by isocratic adsorption HPLC., 56(4), 319-27.

BOBEK, P. E., GINTER, M., JURCOVICOVA, L., KUNLA, K. 1991 Cholesterol lowering effect of mushroom Pleurotus ostreatus in hereditary hypercholesterolomic rats. Annal of Nutrition and Metabolism, 35(4), 191-195.

CURHAN, G. C. 1999. Epidemiologic evidence for the role of oxalate in idiopathic nephrolithiasis. Journal of Endourology, 13(9), 629-31.

DAY, R. A., UNDERWOOD, A. L. 1986. Quantitative analysis. $5^{\text {th }}$ edition, Prentice - hall publication. Upper saddle river, New Jersey, U.S.A. Pp 701.

DEMIRBAS,, A. 2001. Concentrations of 21 metals in 18 species of mushrooms growing in the East Black Sea region. Food Chemistry, 75(4), 453-457. http://dx.doi.org/10.1016/S0308-8146(01)00236-9

Diez, V. A., Alvarez, A. 2001. Compositional and nutritional studies on two wild edible mushrooms from northwest Spain. Food Chemistry, 75(4), 417-422. http://dx.doi.org/10.1016/S0308-8146(01)00229-1

EL-ADAWY, T. A., RAHMA, E. H., EL-BEDAWY, A. A. SOBIHAH, T. Y. 2000. Effect of soaking process on nutritional quality and protein solubility of some legume seeds. Die Nahrung, 44(5), 339 - 343. http://dx.doi.org/10.1002/1521-3803(20001001)44:5<339

EZEIBEKWE, I. O., OGBONNAYA, C. I., UNAMBA, C. I. N., OSUALA, O. M. 2009. Proximate analysis and mineral composition of edible mushrooms in parts of South Eastern Nigeria.Report and Opinion, 1(4), 32-36. http://dx.doi.org/10.1002/1521-3803(20001001)44:5<339

FAO/WHO (1991): Protein quality evaluation. Report of joint expert consultation, In: Food and Agricultural Organization of the United Nations, Rome, Italy. Paper 51.

FOOD AND AGRICULTURE ORGANIZATION OF THE UNITED NATIONS (FAO). 2014 Available online:

http://faostat.fao.org/site/567/DesktopDefault.aspx?PageID=567\#ancor

GEORGII, A., KORTING, H. C. 1991. Antifungal susceptibility testing with Dermatophytes.Mycoses, 34 (5-5), 193-199.

GODFREY, E. Z., SITI, M. K., JUDITH, Z. P. 2010. Effects of temperature and hydrogen peroxide on mycelial growth of eight Pleurotus strains. Scientia Horticulture, 125(2), 95-102. http://dx.doi.org/10.1016/j.scienta.2010.03.006

HALPERN, G. M., MILLER, A. H. 2002. Medicinal mushrooms, M. Evans and Company, Inc, New York.

HANSON, C. F., FRANKOS, V. H., THOMPSON, W. O. 1989. Bioavailability of oxalic acid from spinach, sugar beet fibre and a solution of sodium oxalate consumed by female volunteers. Food and Chemical Toxicology, 27 (3), 181-4. HARBONE, J. B. 1984. Phytochemical methods. a guide to modern techniques of plant analysis London: Chapman and Hall Ltd. ; New York, Pp 49-188.ISBN 0412105403

HRUDAYANATH, T., SAMEER, K. S. 2014. Diversity, nutritional composition and medicinal potential of Indian mushrooms: A review. African Journal of Biotechnology, 13(4), 523-545, http://dx.doi.org/10.5897/AJB2013.13446

CHANDRA, R. K. 1999. Micronutrients and immune functions: An overview. Annals of the New York Academy of Sciences, 587, 9-16.

CHANG, R. 1996. Functional properties of edible mushrooms. Nutrition Review. 54 (11 Pt2), S91-93. 
CHANG, S. T., MILES, P. G. 2004. Mushrooms: cultivation, nutritional value, medicinal effect, and environmental impact, 2nd ed.; Boca Raton, FL, USA: CRC press. ISBN 9780849310430

JIN, X. L., WEI, X., QI, F.M., YU, S. S., ZHOU, B., BAI, S. 2012 Characterization of hydroxycinnamic acid derivatives binding to bovine serum albumin.Organic and Biomolecular Chemistry, $10 \quad$ (17), 3424 31.http://dx.doi.org/10.1039/C2OB25237F

JOHNSON, E. J., RUSSELL, R. M. 2010. Beta-Carotene. In: Coates P. M., Betz J. M., Blackman M. R. edition; encyclopedia of dietary supplements; 2nd edition. London and New York.Pp 115-20.

JOSE, R. A., KAYODE J. 2009. Determination of protein content of some different types of species of mushroom in Owo Local Government Area of Ondo State, Nigeria.Ethnobotanical Leaflets, 13, 917-20.

HAWKINS, P. T., POYNER, D. R., JACKSON, R. R., LETCHER., A. J., LANDER, D. A., IRVINE R. F. 1993. Inhibition of iron-catalyzed hydroxyl radical formation by inositol polyphosphates: A possible physiological function for myo-inositol hexakisphosphate. Journal of Biochemistry, 294(Pt 3), 929 934.

KABIR, Y. S., KIMURA. 1989. Dietary mushrooms reduce blood inhibition of iron-catalyzed hydroxyl radical formation by inositol polyphosphates: A possible physiological function for myo-inositol hexakisphosphate pressure in spontaneously hypertansive rats. Journal of Nutritional Science and Vitaminology, 35, 191-194.

KALAC, P., BURDA, J., STASKOVA, I. 1991. Concentrations of lead, cadmium, mercury and copper in mushrooms in the vicinity of a lead smelter. Science of the Total Environment, 105, 109-119. http://dx.doi.org/10.1016/0048 9697(91)90333-A

KALMIȘ, E., YILDIZ, H., ERGÖNÜL, B., KALYONCU, F., SOLAK, M. H 2011. Chemical composition and nutritional value of a wild edible ectomycorrhizal mushroom, Tricholoma anatolicum.Turkish Journal of Biology, 35, 627-633. http://dx.doi.org/10.3906/biy-0909-100.

KAUR, M., VELMURUGAN, B., RAJAMANICKAM, S., AGARWAL, R., AGARWAL, C. 2009. Gallic acid, an active constituent of grape seed extract, exhibits anti-proliferative, pro-apoptotic and anti-tumorigenic effects against prostate carcinoma xenograft growth in nude mice. Pharmaceutical Research 26(9), 2133-40. http://dx.doi.org/10.1007/s11095-009-9926-y.

KUBMARAWA, D., AJOKU, G. A., ENWEREM N, M., OKORIE, D. A. 2007 Preliminary phytochemical and antimicrobial screening of 50 medicinal plants from Nigeria. African Journal of Biotechnol, 6(14), 1690-1696.

LATUNDE - DADA, G. O. 2006. Effects of processing iron levels in and availability from some Nigerian vegetables. Journal of the Science of Food and Agriculture, 53(3), 355 - 361.

MAKKAR, A. O. S., GOODCHILD, A. V. 1996. Quantification of tannins. A laboratory manual. International Centre for Agriculture Research in the Dry Areas (ICARDA) Aleppo, syria IV+25pp.

McCUTCHEON, A. R., ELLIS, S. M., HANCOCK, R. E. W., TOWER, G. H. N 1994. Antifungal screening of medicinal plants of British Columbian native people. Journal of Ethanopharmacology, 44 (3), 157-169.

MENDIL, D., ULUÖZLÜ, O. D., HASDEMIR, E., ÇAĞLAR, A. 2004 Determination of trace elements on some wild edible mushroom samples from Kastamonu, Turkey. Food Chemistry, 88(2), 281-285. http://dx.doi.org/10.1016/i.foodchem.2004.01.039

MOLE, S.,WATERMAN, P. G. 1985. Stimulatory effects of tannins and cholic acid on tryptic hydrolysis of proteins: ecological implications. Journal of chemical ecology, 11(9), 1323 - 1332. http://dx.doi.org/10.1007/BF01024119 MUHSIN, K., AHMET, A., DURSUN, Y. 2006.Chemical composition of some naturallygrowing and edible mushrooms. Pakistan Journal of Botany, 38(3), 799-804.

NAIDU, P. V. S., KHINTADA, P.M. M. S. P., KALYANI, P. M. 2012 Characterization and biological activities of quercetin thiosemicarbazone derivatives: potential anti cancer drugs. International Journal of Pharmaceutical and Biomedical Science, 3(2), 24-27.

NAKALEMBE, I., KABASA, J. D. 2013. Fatty and amino acids composition of selected wild edible mushrooms of Bunyoro Sub-Region, Uganda. African Journal of Food, Agriculture, Nutrition and Development, 13(1), 7225-7241.

OBOH, G., SHODEHINDE, S. A. 2009. Distribution of nutrients, polyphenols and antioxidant activities in the pileus and stipes of some commonly consumed edible mushrooms in Nigeria. Bulletin of the Chemical Society of Ethiopia, 23(3), 391-398.

OKWU, D. E., JOSIAH, C. 2006. Evaluation of the chemical composition of two Nigerian medicinal plants. African Journal of Biotechnology, 5(4), 357-361. http://dx.doi.org/10.5897/AJB05.251.

ONONUGBU, I. C. 2002. Lipids in human existence. 1st edition. Express Publishing Company, Nsukka, Nigeria. Pp 1-15.

VINHAL, C. O. J., CAVALHO, G. N. M. R., RAMIREZ, A. E. 2012. Nutritiona value of Agaricus sylvaticus; mushroom grown in Brazil. Nutricion hospitalaria, 27(2), 449-455.http://dx.doi.org/10.1590/S0212-16112012000200015.
OSO, B. A. 1976. Mushrooms and the Yoruba people of Nigeria. McIlvainea 2(2), 66-73.

PARIVAR, F., LOW, R. K., STOLLER, M. L. 1996. The influence of diet on urinary stone disease. Journal of Urology, 155(2), 432-40.

PAVEL, K. 2012. A review of chemical composition and nutritional value of wild-growing and cultivatedmushrooms. Journal Science of Food and Agriculture, 93(2), 209-218.http://dx.doi.org/10.1002/jsfa.5960.

PEARSON, D. 1976. Chemical analysis of food. 7th edition. Church Hill Livingstone, London

PETER, R., CHRISTINE, M., PENNIE, T., DEBRA, K., MANNY, N. 2012. Mushrooms and Health; Report prepared for: Mushrooms and Health Global Initiative. Pre-Clinical and Clinical Health Substantiation, CSIRO Food and Nutritional Sciences, Werribee, Victoria Australia Pp 1-13.

PHILLIPPY, B. Q., GRAF, E. 1997. Antioxidant functions of inositol 1,2,3trisphosphate and inositol 1,2,3,6-tetrakisphosphate. Free Radical Biology and Medicine, 22(6), 939 -946. http://dx.doi.org/10.1016/S0891-5849(96)00342-5

PORNARIYA, C., KANOK-ORN, I. 2009. Amino acids and antioxidant properties of the oyster mushrooms, Pleurotus ostreatus and Pleurotus sajor caju. ScienceAsia, 35, 326-331.http://dx.doi.org/10.2306scienceasia1513$\underline{1874.2009 .35 .326}$

RASOOL, M. K., SABINA, E. P., RAMYA, S. R., PREETY, P., PATEL, S., MANDAL, N., MISHRA, P. P., SAMUEL, J. 2010. hepatoprotective and antioxidant effects of gallic acid in paracetamol- induced liver damage in mice.Journal of Pharmacy and Pharmacology, 62(5), 638-43. http://dx.doi.org/10.1211/jpp/62.05.0012.

RIOS, J. L., RECIO, M. C., VILLAR, A. 1988. Screening methods for natural products with antimicrobial activity: A review of the literature. Journal of Ethnopharmacology, 23 (2-3), 127-149. http://dx.doi.org/doi:10.1016/0378 8741(88)90001-3

SABIR, S. M., AHMAD, S. D., HAMID, A., KHAN, M. Q., ATHAYDE, M. L., SANTOS, D. B., BOLIGON, A. A., ROCHA, J. B. T. 2012. Antioxidant and hepatoprotective activity of ethanolic extract of leaves of Solidago microglossa containing polyphenolic compounds. Food Chemistry, 741-

747.http://dx.doi.org/10.1016/j.foodchem.2011.09.026

SHARMA, S. K., ATRI, N. S., JOSHI, R., GULATI, A., GULATI, A. 2012 Evaluation of wild edible mushrooms for amino acid composition. Academic $\begin{array}{llll}\text { Journal of } & \text { Plant } & \text { Sciences, } & 5(2),\end{array}$ http://dx.doi.org/10.5829/idosi.ajps.2012.5.2.240

SIES, H., 1997. Oxidative Stress: Oxidants and antioxidants. Experimental physiology, 82(2), 291-5. http://dx.doi.org/10.1113/expphysiol.1997.sp004024 SOFOWORA, A. 1993. Medicinal plants and traditional medicines in Africa. Chichester John Wiley and Sons New York. Pp 97-145. ISBN 9782462195, 9789782462190

SOLAK, M. H., KALMIȘ, E., SAĞLAM, H., KALYONCU, F. 2006.

Antimicrobial activity of two wild mushrooms Clitocybe alexandri (Gill.) Konr. and Rhizopogon roseolus (Corda) T. M. Fries collected from Turkey.

Phytotherapy Research, 20, 1085-1087. http://dx.doi.org/10.1002/ptr.2002

SOLOMONS, N. W. 2006. Vitamin A. In: Bowman B., Russell R. Edition. Present knowledge in nutrition. 9th ed. Washington, DC: International Life Sciences Institute.157-183.

SRINIVASAN, D., NATHAN, S., SURESH, T., PERUMALSAMY, P. L. 2001 Antimicrobial activity of certain Indian medicinal plants used in folkloric medicine. Journal Ethnopharmacology, 74 (3), 217-220. http://dx.doi.org /doi:10.1016/S0378-8741(00)00345-7.

TREASE, G. E., EVANS, W.C. 1989. Pharmacognosy. $13^{\text {th }}$ Edition, Bailliere Tindall, London. Pp 176-180.

DEMBITSKY, V., MTERENT'EV, O. A., LEVITSKY, D. O. 2010. Amino and fatty acids of wild edible mushrooms of the genus Boletus. Records of Natural Products, 4, 218-223. URL-1, 2005. Medicinal mushrooms a light in the dark: htm http://www. Nutraceut icalsworld.com/guide1.htm.

VETTER, J. 1994. Potassium content of edible wild mushroom species Zeitschrift für Lebensmittel Untersuchung Forschung, 198, 33-35.

VETTER, J. 2003. Data on sodium content of common edible mushrooms. Food Chemistry, 81, 589-593. http://dx.doi.org/10.1016/S0308-8146(02)00501-0

WALLE, T. 2004. Absorption and metabolism of flavonoids. Free Radical Biology and Medicine, 36(7), 829-837. http://dx.doi.org /10.1016/j.freeradbiomed.2004.01.002

WANI, B. A., BODHA, R. H., WANI A. H. 2010. Nutritional and medicinal importance of mushrooms. Journal of Medicinal Plants Research, 4(24), 25982604. http://dx.doi.org/10.5897/JMPR09.565

WASSER, S. P. 2002. Medicinal mushrooms as a source of antitumor and immunomodulating polysaccharides. Applied Microbiology and Biotechnology, 60(3), 258-274.http://dx.doi.org/10.1007/s00253-002-1076-7

YADAV, P. R., TYAGI, R. 2006. Lipid Biotechnology, 1 Discovery Publishing House - New Delhi. Pp 89.

YAOQI, Z., WEI, G., YUEQIN, S., YANLING, W., YU-CHENG, D. 2014 Edible mushroom cultivation for food security and rural development in china: 
bio-innovation, technological dissemination and marketing. Sustainability, 6, 2961-2973. http://dx.doi.103390/su6052961

YAVELOW, J., PINKY, T. H., KENNEDY, A. R., TROLL, W. 1983. Bowmanbirk soybean protease inhibitor as an anticarcinogen. Cancer Research, 43(5), 2454s-2459s.

YUN-ZHONG, F., SHENG, Y., GUOYAO, W. 2002. Regulation of

physiological systems by nutrients; free radicals, antioxidants, and nutrition.

Nutrition, Elsevier Science Inc.18, 872- 879. http://dx.doi.org/10.1016/S0899-

9007(02)00916-4 